\title{
Para um diálogo entre ciência política e science studies
}

\author{
BRUNO LATOUR \\ Institut d'Etudes Politiques de Paris, Paris, França \\ bruno.latour@sciences-po.fr \\ Tradução: GUILHERME DE MATOS FLORIANO \\ Universidade Estadual Paulista, Araraquara, São Paulo, Brasil \\ guilherme.mfloriano@hotmail.com \\ Revisão Técnica: RenATA MedeIRos PaOliEllo \\ Universidade Estadual Paulista, Araraquara, São Paulo, Brasil
}

DOI 10.11606/issn.2316-9133.v29i1p112-137

resumo Ciência política e estudos da ciência (Science studies) usam a palavra "política" e "ciência", e mesmo assim seus significados são tão diferentes que parecem incomensuráveis: faz-se um esforço para explicar aos cientistas políticos os vários usos dessas palavras tal como usadas por estudiosos da ciência e como eles podem relacionar-se à ciência política, especificamente. $\mathrm{O}$ artigo propõe explicar aos especialistas em ciências políticas o emprego, um pouco incomum, que é feito destes termos pelos praticantes dos estudos sobre as ciências, de modo a estabelecer um diálogo entre as duas disciplinas. Mostra em particular que apenas um sentido da palavra "ciência" (entre quatro) supõe um corte radical entre ciência e política (que pode tomar seis sentidos). Este esforço de esclarecimento realizado permitiria abandonar a ideia que existe duas áreas distintas (a ciência e a política) e permitiria às duas disciplinas colaborar qualificando os diferentes estados dos assuntos (issues) que formam a verdadeira substância das ciências assim como das políticas.

palavras-chave política; ciência; Science studies.

\section{A Dialogue between political science and science studies}

abstract The two disciplines of political science and science studies both use the words "politics" and "science", and yet their meaning are so different that they seem incommensurable: an effort is made to explain to political scientists the various uses of those words as it is used by the science studies practitioners and how they could relate to political science properly speaking. The paper shows that only one meaning (out of four) of the word "science" does actually distinguish it in a radical way from "politics" (which may take six 
different meanings). Once those meanings have been circumscribed, instead of defining distinct domains of science and politics, a more fruitful collaboration between science studies and political science could be developed around the following of issues.

palavras-chave Politics. Science. Science studies.

\section{A mesma questão da epistemologia política'}

Embora as coisas tenham mudando profundamente desde o retrato cruzado do professor universitário alemão e do funcionário de Estado traçado por Max Weber, nós ainda o utilizamos para resumir as problemáticas entre a ciência e a política. Entretanto, em um século, muitos outros autores entraram em cena, obscurecendo mais e mais a cada dia a separação de papéis entre o "cientista" e o "político". O que os pesquisadores podem fazer para divulgar suas descobertas por conferências de imprensa? Os militantes ecologistas que testemunham como experts os processos contra as companhias petroleiras? Os advogados especialistas em patentes que acampam nos laboratórios? O conselho de administração de uma associação de pacientes que decide financiar tal ou qual pesquisa em biologia molecular? O ministério de Pesquisa que impõe a compra de livros de protocolos padronizados? Um governador americano que introduz na constituição de seu Estado a obrigação de sustentar as pesquisas sobre as células-tronco? Os físicos dissidentes que se tornaram denunciantes de seu próprio instituto de pesquisa? Os deputados que organizam as conferências de consenso sobre questões tecnológicas altamente controversas? Os especialistas em climatologia que votam no grupo de pesquisa sobre o clima, o IPCC ${ }^{2}$, sobre a probabilidade de causas do aquecimento global - e recompensar um prêmio Nobel da paz? Surpreendentemente, apesar da proliferação de novos atores, ainda não está claro pelo que substituir uma divisão que parece um pouco obsoleta e, ainda, indispensável.

Tal como em muitas outras matérias de ciência social, percebemos que uma solução possível consiste em tomar essa distinção como objeto de estudo ao invés de considerá-la como um recurso indiscutível. Há uma história de distinções sucessivas entre ciência e política, história que se torna documentável sob a condição de suspender antecipadamente A distinção entre a esfera do político e aquela da ciência.

Mesmo que esse programa exista há muito tempo, sua fertilidade não se tornou realmente visível aos olhos dos pesquisadores em ciências políticas senão através da obra mestra de Steve Shapin e Simon Schaffer (1993) sobre as relações de Boyle e Hobbes. Ao invés de ignorar a ciência de Hobbes e a política de Boyle como fizemos antes deles, ou, de modo um pouco mais avançado, ao invés de tratar os assuntos tensos de Boyle e de Hobbes

\footnotetext{
${ }^{1}$ Traduzido do original LATOUR, B. Pour un dialogue entre cience politique et cience studies. Revue française de science politique, vol. 58, no 4, août 2008, p. 657-678. Disponível em: https://www.cairn.info/revuefrancaise-de-science-politique-2008-4-page-657.htm

${ }^{2}$ Nota do tradutor: Latour usa a sigla GIEC em francês. No Brasil, utilizamos a sigla em inglês, referida ao Intergovernmental Panel on Climate Change. Em português: Painel Intergovernamental sobre Mudanças Climáticas.
} 
como se um representasse a ciência e o outro a política, o gênio deste livro foi levar a sério, em Hobbes, a ciência e, em Boyle, a política. Ou, mais ainda, mostrar como se inventou, em ambos os autores, o extremamente delicado e controverso limite das fronteiras entre variadas cosmologias que deram, por um lado, a forma de vida experimental que associamos à química de Boyle e, por outro lado, um novo regime de autoridade em Hobbes.

Ao invés de nos determos na história convencionada da "Revolução científica", vimos neste livro a oposição de duas cosmologias, dois cosmogramas (TRESCH, 2005), um, de Boyle, que associava um certo estilo literário, uma definição de Deus, uma concepção do vazio, as experiências sobre a bomba de ar, uma convocação da prova pelos cavalheiros estudiosos, uma ideia particular de apoio real; o outro, de Hobbes, no qual podíamos localizar outra definição de Deus, outra definição do vazio, uma definição absolutamente contrária do estilo e de prova, uma profunda desconfiança nas assembleias de cavalheiros estudiosos e, como sabemos, uma noção bastante diferente de autoridade, de dedução, de experiência e de censura. Neste trabalho magistral, as áreas da ciência e da política se encontram progressivamente dissolvidos, recolocados pela lista de ingredientes que definem cosmologias cada vez mais irreconciliáveis. São estes cosmogramas que devem ser distinguidos, embora misturem elementos dispersos da antiga "área" das ciências e da antiga "área” da política.

Como mostra o livre, tardiamente, e somente através das definições do século XIX, que poderemos esquecer a política de Boyle e a ciência de Hobbes e trata-los separadamente, transformando um na figura tutelar da física ou da química experimentais e o outro no próprio símbolo da ciência política - antes de se colocar a grande questão das "relações entre o cientista e o político"... Uma vez feita a distinção, raros eram os departamentos de química que se lembraram da teologia política de Boyle e os departamentos de ciência política que se recordavam do quanto Hobbes esperou ter contribuído para uma ciência finalmente demonstrada. Ao assumir todo o assunto da Revolução científica, Shapin e Schaffer revascularizaram, por assim dizer, uma questão que tínhamos amputado totalmente servindo-nos da distinção ao invés de a tomarmos por objeto de estudo.

Apesar da importância reconhecida deste livro, não me parece que houve verdadeiramente um debate frutífero entre ambas as áreas que utilizam as mesmas expressões: aquele da ciência política de um lado e, de outro, aquele dos estudos sobre a política das ciências e das técnicas, que resumimos costumeiramente pela expressão inglesa de "science studies".

É este o debate de epistemologia política que quero prolongar nas páginas da Revista Francesa de Ciência Política, ensaiando esclarecer inicialmente uma questão de vocabulário.

Fico impressionado com o fato de que a combinação dos dois termos "ciência" e "política” não suscite as mesmas reações nas duas disciplinas. Para as ciências políticas, apenas de suas múltiplas nuances, parece que a palavra "ciência" define um método, uma maneira sistemática, seria, rigorosa, empírica de abordar um objeto - o "político" ou a "política" cujos limites variam de acordo com cada autor, mas cuja delimitação é, em princípio, possível 
(GRAWITZ; JECA, 1985). A combinação das duas palavras tem, então, quase a mesma função que nas áreas de conhecimento como as "ciências da religião", as "ciências da linguagem", as "ciências administrativas". Em consequência, nada mais que o que os sufixos de "-logia" ou de "-grafia" acoplam às outras áreas do conhecimento, como a sociologia ou a geografia.

No entanto, este não é de modo algum o caso em outra área, muito mais recente, aquele dos Science studies. Traduzindo para o inglês a expressão grega "epistemologia”, o sentido das duas palavras "ciência" e "política" modificou profundamente (PESTRE, 2006; HACKETT et al, 2007). Ainda que na expressão "ciência política" a combinação dos dois termos não implique grandes problemas - ele apenas desenvolve as ciências sociais, humanas, jurídicas ou, talvez, "camerais", em direção a uma nova área que servirá tão bem quanto os precedentes -, o mesmo não acontece no segundo: aqui, nos encontramos diante de uma poderosa reação química, para não dizer uma explosão.

Na verdade, na expressão "história política das ciências", são ambas a política e a ciência que se tornam objetos, ó quantas controvérsias de uma mesma série de questões sistemáticas. Que Boyle tem também ideias sobre a realeza e que Hobbes tenha uma opinião sobre a matemática, é o que não pode assustar nem os historiadores das ciências nem os da história das ideias políticas. Mas que a concepção do vácuo de Boyle veio modificar de forma profunda o que podemos esperar da matéria e, portanto, da ordem social, que a concepção de Hobbes sobre a prova veio modificar o que podemos esperar da autoridade, portanto, do Soberano, é o que vai desfazer toda possibilidade de reagrupar as atividades cientificas em uma esfera e as atividades políticas em outra. Mais que isso, vamos lançar a dúvida tanto sobre as capacidades da ciência em falar sozinha sobre a cultura - pois é também de ordem social que se trata - quanto sobre as capacidades da política em falar da soberania - pois é também de prova matemática que se trata. E não temos o conforto de poder dizer que o que foi, talvez, verdade no século XVII não é o certamente mais em nosso: que um prêmio Nobel da Paz venha recompensar o IPCC prova o suficiente que é toda a geografia que se encontra agitada por uma questão de modelização matemática do clima da Terra.

Enquanto a ciência política não precisa necessariamente fazer a questão de princípio sobre a legitimidade de um estudo científico de sua área particular - a política - (mesmo se os conflitos de método e de definição abundem ${ }^{3}$ ) - é a ideia mesma de uma distinção das ciências naturais ou sociais com a política - e mais geralmente a "sociedade" - que é o assunto específico dos estudos sobre as ciências e mesmo, até certo ponto, seu obstáculo (LATOUR, 1999). Enquanto a ciência política pode confiar em uma certa versão - normalmente instituída e estabilizada - da distinção entre um método de pesquisa (a ou as “ciências") e um objeto constituído (o, a, os ou as "políticas(os)"), são precisamente todas as versões sucessivas desta distinção, ela mesma, que formam o objeto próprio dos Science studies - para não dizer seu tormento particular. Uma coisa é certa: se as questões de epistemologia política são

\footnotetext{
${ }^{3}$ cf. Favre (2005).
} 
comuns às duas áreas, a relativa tranquilidade com a qual a ciência política lida com os dois termos não se encontra na dos estudos sobre a política das ciências ${ }^{4}$.

É por isso que eu gostaria que este artigo compartilhasse essa preocupação e tranquilidade de maneira mais equitativa! Como a ciência política poderia tomar como recursos legítimos as ideias de "ciência" e de "política" quando estas ideias são, na melhor das hipóteses, apenas resultados provisórios de uma história da ciência e da política que permanece ainda largamente fora do campo? Por outro lado, como os estudos sobre a ciência poderiam afirmar "politizar a ciência", até esse ponto, sem ter interesse nos imensos recursos da ciência política para falar sobre a política? Em princípio, uma dupla preocupação deve confundir as duas áreas: a ciência política deve ficar perplexa que possamos colocar em causa tanto seu método quanto seu objeto; os Science studies devem se envergonhar pelo fato de que a palavra "política" aparece com tanta frequência sem saber claramente o que isso significa (DE VRIES, 2007). À primeira vista, as interseções devem ser grandes o suficiente para que as questões de epistemologia política formem, por muito tempo, um espaço frutífero de troca.

Na prática, além disso, as relações entre as duas áreas já são numerosas uma vez que o terreno de estudo frequentemente as obriga, tanto eles misturam a ciência, a técnica e a política, recorrendo aos conceitos tanto da ciência política quando dos Science studies 5 . Enquanto a cada dia mais os temas dos doutorandos que temos em comum, a redação dos concursos públicos aos quais respondemos em conjunto, as preocupações do público convergem nos objetos de pesquisa - as crises ecologias, as questões urbanas, as novas técnicas de informação, as controvérsias sobre a ciência, os instrumentos da globalização, a apreensão dos riscos, as novas técnicas militares, etc. - a tal ponto que é difícil saber se fazemos parte da área da ciência política ou àquele da política das ciências, mas me parece, apesar de tudo, que os empregos que ambos fazemos dos termos "ciência" e "política" permanecem incomensuráveis. Ou, ao menos, até agora não foram objeto de esforço comum de calibração.

Não podendo falar em nome da ciência política, gostaria de, para levar a linguagem, apresentar aos meus colegas como esse pequeno problema de padronização poderia eventualmente ser colocado do ponto de vista da minha disciplina, o estudo da ciência.

Infelizmente, não podemos fazer justiça à espinhosa questão da ligação entre nossas duas áreas sem precisar, do lado da política, seis acepções diferentes e quatro do lado da ciência - são dez, eu sei, sem contar suas combinações. Eu me desculpo de antemão: eu preferiria poder abrir o debate de maneira mais concisa, mas a única utilidade deste artigo é de que não deve simplificar artificialmente o assunto. O padronizador não deve fingir cortar o nó górdio, mas saber também, quando necessário, cortar o cabelo em quatro. Os leitores da revista decidirão, a seguir, se a "negociação" deve continuar ou não entre os pesquisadores

\footnotetext{
${ }^{4}$ Ver os recentes dossiês reunidos nas duas principais revistas da área: Social Studies of Science, em particular o volume 37, outubro de 2007, e Science Technology and Human Values.

${ }^{5}$ Como evidenciado, para dar alguns exemplos e para se manter na França, entre muitos outros, Lolive (1999) Chateauraynaud e Torny (1999), Callon, Lascoumes e Barthe (2001), e o volume editado por Gilbert (2003).
} 
de uma área tão confusa... Mas, antes de decidir, que se lembrem, apesar de tudo, que é o próprio mundo atual que nos coloca imbróglios demasiado improváveis para que aprendamos a os desembaraçar.

\section{Cinco (mais um) sentidos diferentes do termo "política"}

Para seguir os diferentes sentidos da palavra política, tal como empregada em nossa disciplina (e sem muita conexão no começo, admito, com os da ciência política ${ }^{6}$ ), deve-se aceitar suspender totalmente a ideia que haveria uma área própria - o ou a política - distinto ou separável, em princípio, das outras áreas. Em certo sentido, aceitamos o slogan, ainda vivo, que "tudo é político" ou, ao menos, que "a política está em todo o lugar". A razão deste modo preguiçoso de colocar a questão é que nós frequentemente estudamos situações nas quais novos seres, desconhecidos até então, irrompem na vida comum modificando, às vezes de cima para baixo, a lista de membros do que eu chamo, por esta razão, um coletivo.

Para tomar um exemplo famoso, quando Einstein pega sua pena para escrever e alertar o presidente Roosevelt do perigo como trunfo que representa o controle das reações nucleares, ele faz ou não faz política? Não, certamente, no sentido do que poderia interessar um especialista em eleições americanas de acordo com o New Deal. Mas, todo mundo admite facilmente, ele faz política mais diretamente na medida em que, doravante, os átomos e seu controle farão parte do arsenal militar, constituirão uma das principais preocupações geopolíticas, ocuparão as áreas inteiras da administração, preocuparão os novos grupos de militantes. O caso é simples já que Einstein se endereça à um presidente legitimamente eleito, pelos canais mais clássicos do lobbying. Não há, portanto, nenhuma dificuldade em prolongar o sentido da palavra política.

Mas para compreender o que verdadeiramente interessa aos Science studies, devemos prolongar mais um pouco, para chegarmos ao cerne os aspectos mais técnicos do trabalho propriamente científico de Einstein. De fato, não vivemos mais no mesmo mundo no qual podemos, através das transformação de Lorenz, mostrar os quadros de referência (mesmo acelerados) compatíveis, ou se, por falta de relatividade restrita mais geral, os quadros de referencia permanecem incomensuráveis, tornando os movimentos impossíveis de calcular e, consequentemente, o universo incompreensível. O que está em questão na teoria da relatividade é que o universo inteiro se torna cognoscível apesar da dispersão de pontos de vista (FEUER, 2005; GALISON, 2005a; LATOUR, 1988). Esta é uma questão política no sentido restrito do termo? Certamente não, não é senão sobre as questões mais esotéricas da física. É por isso, então, uma questão estritamente apolítica? Certamente não, pois com ou sem a relatividade não temos acesso às mesmas dimensões do universo. Literalmente não nos movemos mais livremente no mesmo mundo. Tocar os quadros do espaço e do tempo, sem dúvida alguma, sabemos desde Marcel Mauss, é tocar os próprios fundamentos da existência comum.

\footnotetext{
${ }^{6}$ Para um exemplo recente dessa incomensurabilidade, ver Donegani e Sadoun (2007), cuja definição proposta não se sobrepõe aquela proposta aqui.
} 
Mas agora, se "tudo é político", como emergir da confusão onde corremos o risco de prolongar este slogan vazio? Não podemos mais nos limitar à existência de uma esfera na qual se reuniriam atividades "estritamente políticas" e que poderíamos, em seguida, distingui-las de outras esferas, econômica, jurídica, científica etc. A solução que escolhi para tentar calibrar nossas definições um pouco contraditórias consiste não em definir de antemão uma área do político, mas em qualificar por uma sucessão de termos as etapas sucessivas através das quais passam os objetos controversos, os assuntos ${ }^{7}$, aquilo que os ingleses chamam de "issues", cuja multiplicidade define empiricamente os numerosos pontos de contato entre as questões comuns às nossas duas disciplinas. Em outras palavras, ao invés de partir das esferas tentando sem esperança de as distinguir, e em seguida de reconectá-las, proponho partir dos casos e ver de quantas maneiras diferentes podemos qualificar seus movimentos. Afirmo que, embora seja impossível definir claramente as palavras "política” e "ciência”, é perfeitamente possível qualificar a sucessão das etapas pelas quais transitam os objetos controversos.

\section{Política $=$ novas associações}

O exemplo de Einstein não é único. Seria o mesmo se falássemos dos micróbios de Pasteur (LATOUR, 2001a), da descoberta do magnetismo (PESTRE, 1990), das campanhas do Genethon (CARDON et al, 1998; CALLON; RABEHARISON, 1999), da energia nuclear na França (HECHT, 2004), das nanotecnologias, das equações das finanças (MACKENZIE, 2006), ou da gripe aviária, etc. Neste ponto, ao menos, creio que podemos considerar a causa como entendida: a área da política em seu sentido usual parece, sem cessar, demarcado pela irrupção de novos seres que demandam serem tomados em conta e, depois de três séculos mas cada dia mais intensamente, cuja imensa maioria provém dos laboratórios - no sentido mais amplo do termo, não esquecendo, evidentemente, de incluir aqueles das ciências sociais e camerais (DESROSIÈRES, 1993).

Para dar outro exemplo, o que aconteceria se os astrônomos, através de um novo instrumento, começassem a descobrir com certeza não mais um ou dois, mas centenas de planetas fora do sistema solar. Atividade "estritamente científica" e "claramente apolítica" para os praticantes. Para os Science studies, ao contrário, um coletivo com ou sem exoplanetas não é mais o mesmo coletivo, não forma mais as mesmas associações, está fundamentalmente transformado. Não vivemos mais no mesmo cosmos, no mesmo universo, no mesmo mundo se existe um único planeta, nossa boa e velha Terra, ou uma infinidade de planetas alguns dos quais são suscetíveis de desenvolver as formas de vida. Além disso, se hesitamos "politizar" uma questão tão técnica, basta nos lembrar de Giordano Bruno. A questão permanece ainda hoje pungente... E será assim cada vez que modificarmos as associações entre os seres do coletivo. A descoberta dos exoplanetas é política? Com certeza não. É

\footnotetext{
${ }^{7}$ O sentido é próximo ao esclarecido em Offenstadt et al. (2007) e, mais geralmente, nos trabalhos de Luc Boltanski e do GSPM.
} 
política? Sim, sem dúvidas: uma grande reviravolta é introduzida na ordem do mundo dependendo de multiplicar ou reduzir este número.

É o primeiro sentido que podemos reconhecer na palavra política na área dos estudos sobre as ciências: aquele de uma nova associação. Muito mais solto, provavelmente, que aquele que aceitaríamos na ciência política propriamente dita, mas que forma, entretanto, abaixo, a matéria primeira das reviravoltas técnicas e econômicas as quais a vida pública deverá enfrentar. Não, as ciências não vêm acalmar, por seu admirável rigor, as desordens da vida pública: elas vêm, por suas involuntárias (e às vezes voluntárias) turbulências, transformar constantemente a lista, o ordenamento, a hierarquia, a composição dos seres para se reunir em um mundo comum que seja um pouco decente e habitável.

Este primeiro sentido, de fato, corre o risco de parecer paradoxal uma vez que parece estritamente apolítico aos olhos dos praticantes, do público e de uma parte dos analistas. Entretanto é, para nós, o sentido mais diretamente, mais universalmente, mais violentamente político $^{[1]}$ (para facilitar a identificação, adicionarei neste artigo indícios de cada uso desta palavra polissêmica).

\section{Política = o que assenta novamente o problema do público}

É aqui que devemos introduzir um segundo sentido da palavra política: certas controvérsias nos obrigam a modificar também a definição do público? Fico feliz em saber que a imensa maioria das novas associações propostas, no decorrer das páginas, no banco de dados de patentes, nas revistas científicas, nos centros técnicos, incomodam apenas uma ínfima minoria de pessoas e não se tornarão jamais "políticas" neste segundo sentido (embora sejam todas, por definição, como acabei de dizer, políticos ${ }^{[1]}$ ). Para que elas se tornem políticas $^{[2]}$, as formas instituídas pelas quais o coletivo se pensa e se administra devem se encontrar explicitamente perturbadas.

Admito de bom grado que a questão dos exoplanetas não se tornou política ${ }^{[2]}$ (ao menos não ainda, a menos que o Tribunal de Inquisição não se incline ainda sobre esta questão...). Nenhum administrador, nenhum grupo de cidadãos, nenhum blog, se colocou ainda a questão dos exoplanetas como um assunto de disputa que vai colocar em questão a organização de nossas instituições, de nossos procedimentos, de nossos modos usuais de regulação de conflitos. Para tomar os termos de John Dewey, o público sobre este caso não se tornou ainda, segundo a expressão de Walter Lippman, um problema (LIPPMANN, 2008; MARRES, 2007).

Lembremos que para estes dois pragmáticos, de fato, o público não começa a emergir senão quando os procedimentos usuais que permitem a apreensão, tateando as consequências inesperadas das ações comuns, faliram umas após as outras (DEWEY, 2003). Se o público aparece, é porque as autoridades não sabem mais o que fazer, que devem reinventar as novas regras e os novos procedimentos (ZASK, 2000). De início "eclipsada" pela novidade das questões colocadas, a comunidade deve, em seguida, pouco a pouco se recompor. 
Mas sobre outros assuntos, é evidente que a grande questão de Dewey se cola muito claramente e que todas as formas habituais de vida comum se encontram profundamente colocadas em causa. O caso dos $\mathrm{OGM}^{8}$ é talvez o mais impressionante: embora uma quinzena de anos de inovações nos procedimentos, nas leis e nos regulamentos, a formação de um público ad hoc para este caso se encontra ainda muito incerta. Mais geralmente, a leitura dos quotidianos multiplica agora os assuntos de controvérsia onde vemos claramente que o público se encontra, para cada assunto, impossível de representar, de reunir. O, ou mais ainda, os públicos - ainda no sentido de Dewey e não aquele do espaço público (REYNIÉ, 1998) - permanecem um problema, seja a reintrodução dos ursos eslovenos nos Pirineus, dos modelos de evolução do clima global ou das quotas de pesca no mar de Iroise (MARRES, 2005).

Notemos um ponto importante que poderia levar um mal entendido com aqueles que querem continuar a separar ciência e política em esferas distintas. Um assunto que se torna político ${ }^{[2]}$ no segundo sentido, não se parece de forma alguma àquele que os cientistas chamam costumeiramente de "politização" indevida, injustificada, incontrolada, de um problema que "deveria permanecer" "estritamente técnico ou científico" ${ }^{9}$. Na definição que proponho, não há mais, de um lado, problemas científicos e técnicos e, de outro, problemas políticos que "infelizmente, se misturam", talvez, pela confusão dos bons cidadãos. Veremos adiante quais indicações devemos dar aos três termos "politização", "racionalistas" e "estritamente científico" nesta forma habitual de falar que é justamente aquela na qual os Science studies felizmente nos livrou. Bem ao contrário, os assuntos políticos ${ }^{[2]}$ são uma das respostas possíveis às inovações introduzidas pela política ${ }^{[1]}$. Como disse admiravelmente Dewey (depois de Lippmann), não tomamos a questão do público senão quando há desamparo, destruição, quebra das formas usuais de tratamento da vida comum. Tudo se passa como se certas inovações cientificas e técnicas obrigassem a recompor o quebra-cabeça da vida comum com novas peças ${ }^{10}$.

\section{Política = onde se coloca a questão da soberania}

$\mathrm{O}$ contraste se faz bastante claro com o terceiro sentido que podemos dar à palavra política nos assuntos perseguidos pelos estudos sobre as ciências. Não se trata mais dos novos seres que romperiam as associações habituais; não se trata, tanto mais, da incerteza sobre o dispositivo que poderia eventualmente resolver a questão do público abalado pela irrupção de novos "issues", mas de assuntos nos quais se coloca claramente para um coletivo, normalmente para um Estado, a questão própria da soberania, da sobrevivência. O sentido comum não terá problemas em reconhecer sua questão. "Desta vez, trata-se de assuntos verdadeiramente políticos. Os exoplanetas, a teoria da relatividade, os OGM, não sabíamos muito bem o que fazer deles, mas se vocês nos falassem da guerra e da paz, de amigo ou

\footnotetext{
${ }^{8}$ Nota do tradutor: Organismos Geneticamente Modificados

${ }^{9} \mathrm{O}$ mesmo ponto é dado em Lagroye (2003).

${ }^{10}$ Sobre a noção de "composição progressiva do mundo comum", ver Latour (1999)
} 
inimigo, de dominação e de poder, aí sim, estamos em terra de conhecimento.” Neste caso, é mais para Carl Schmitt que para John Dewey que deveríamos nos virar. E, entretanto, se esses assuntos são realmente políticos ${ }^{[3]}$, eles não devem nos deixar esquecer que os dois outros sentidos que se aplicam aos casos infinitamente mais numerosos e cujas trajetórias nunca podem passar por esta etapa ${ }^{11}$.

O que há de particular a algumas causas que se politizam ${ }^{[3]}$ desta maneira, é que encontramos nelas, ainda que se trate de questões de ciência, os mesmos desafios que para todas as grandes questões familiares da ciência política. Citei, mais acima, a carta de Einstein: vemos facilmente que o programa Manhattan vai, em alguns meses, e quase sem ruptura, colocar o problema da reação em cadeia - e portanto da aparelhagem gigantesca necessária à sua industrialização - entre os desafios mais candentes da soberania, os arcanos mais sombrios do poder, as questões mais angustiantes da arte militar. Sobre muitos pontos será o mesmo para o caso dos OGM, ao menos para os europeus e para certos militantes: ela se torna claramente uma das controvérsias nas quais se coloca a soberania - quem possui o direito de plantar? Quem possui a vida? - e, em certos sentidos, uma questão de vida e de morte - para o campesinato, para o planeta, para certos agricultores encurralados entre o suicídio ou a prisão.

Desde a intensificação das crises ecológicas, é, além disso, a união das questões do clima, da política energética, do urbanismo, etc. que se tornam as grandes questões da soberania, as questões nas quais se põem para um coletivo o momento chave da decisão de ser ou de não mais ser. Como compreender de outra maneira que a Califórnia, para seu governador, se define em parte pelo que ela apreenderá das células-tronco e carros limpos ${ }^{12}$ ? Não juremos que a questão dos exoplanetas não se tornará uma questão política ${ }^{[3]}$ : se um dia tivéssemos que deixar nossa Terra devastada, não deveríamos dizer daqueles que supervisionaram o êxodo que eles enfrentam, da forma mais radical que seja, a grande questão schmittiana da decisão? Certamente pode parecer estranho associar as questões da soberania com os assuntos advindos das ciências naturais, mas seria limitar demais a extensão da ciência política ${ }^{13}$. Há muito tempo que os termos de amizade e inimizade não se designam mais apenas aos humanos; muitos outros imbróglios exigem retomar, com novas despesas, toda a questão da soberania. Os termos de guerra e paz se aplicam também aos micróbios...

\footnotetext{
${ }^{11}$ É mais o interesse do caso descrito por G. de Vries (2007), que mostrar como um issue pode, apesar de todos os esforços aplicados, jamais passar nesse estado.

12 "Sect. 4. Article XXXV is added to the California Constitution, to read : There is hereby established a right to conduct stem cell research which includes research involving adult stem cells, cord blood stem cells, pluripotent stem cells, and/or progenitor cells. Pluripotent stem cells are cells that are capable of self-renewal, and have broad potential to differentiate into multiple adult cell types. Pluripotent stem cells may be derived from somatic cell nuclear transfer or from surplus products of in vitro fertilization treatments when such products are donated under appropriate informed consent procedures".

${ }^{13}$ Ver o surpreendente imbróglio desenhado no livro de Barthe (2006), onde a questão dos resíduos nucleares chega ao ponto de modificar a noção de decisão, este topos da teoria de soberania.
} 


\section{Política = Questão de um procedimento democrático}

O contraste se vê melhor ainda com o quarto sentido da palavra política, aquele que poderemos, com toda a justiça, atrelar, desta vez, ao nome de Jürgen Habermas mais que ao de Dewey. Trata-se de trazer negócios, que as inovações científicas e técnicas proliferam no regime usual da discussão democrática. Por oposição àqueles que permanecem políticos ${ }^{[2]}$ ou políticas ${ }^{[3]}$ - e a fortiori políticos ${ }^{[1]}$-, supõe-se que os procedimentos já existem, que sejam considerados como legítimos, que haja um acordo mínimo sobre a forma de tratar as novas problemáticas, bem como a aceitação prévia pela minoria do respeito pela decisão final. Dito de outra forma, tudo o que faz falta nos precedentes.

Podemos zombar desta concepção idealista da discussão racional. Podemos duvidar que as questões assustadoramente técnicas como estas, por exemplo os OGM ou as nanotecnologias, possam retornar de maneira cômoda. Os numerosos exemplos retirados da experiencia da "participação do público nas decisões cientificas e técnicas" podem, com razão, engendrar certo ceticismo (JOLY; MARRIS; HERMITE, 2005; JOLY; MARRIS, 2003; FOURNIAUX , 2007). Podemos até prever que os participantes destes casos tenderão mais a ir além dos procedimentos, a recusar os representantes escolhidos e, juntos, a oscilar os problemas em uma situação "à Dewey" de política ${ }^{[2]}$ ou "à Schmitt" de política ${ }^{[3]}$.

Entretanto, sem que nos dermos conta, existe uma multidão de questões que são abordadas, a cada dia, pelos procedimentos deste tipo, apesar de terem sido, de início, políticos nos sentidos precedentes. Os cantões inteiros da administração, que se tratasse das vacinas, da prevenção de incêndios, da definição dos mapas de zonas de risco, da colocação de medicamentos nos mercados, da venda de direitos à poluição, e assim por diante, obrigam pelos procedimentos legítimos às decisões disputadas e discutidas. É bem o que desenhamos quando falamos de "política da saúde" ou de "política dos riscos".

Diremos que quase não há diferença agora com o que chamei segundo e terceiro sentidos, já que o mesmo caso pode flutuar de um a outro destes quatro sentidos. Mas há, entretanto, no último caso uma tonalidade distinta, é a que distingue a política daquilo que hoje chamamos de governança. Embora todos estes assuntos sejam técnicos, eles não carregam a colocação em causa dos procedimentos (a questão do público, no sentido de Dewey, não se coloca aí ou mais), nem não se finge na angustia do "momento de exceção" e é também por esta razão que os colocamos do lado da administração. Todos estes assuntos que provém costumeiramente dos laboratórios, embora sejam sempre de uma alta tecnicidade (o mesmo tanto que o direito, as ciências administrativas, a contabilidade, as ciências econômicas, a meteorologia adicionam quase sempre sua confusão às da física, da química, da biologia), aparecem, entretanto, às partes interessadas como tratáveis. Basicamente, sabemos o que fazer; sabemos que é representativo; sabemos qual regra seguir; temos as informações válidas; sabemos por qual procedimento e como tomar a palavra. Não há incerteza senão da decisão final. Compreendemos, então, a atração que representa este senso de política e porquê podemos querer desejar estendê-lo. Se será perigoso querer 
reduzir a política à governança, não é absurdo reconhecer que certos assuntos são bem politizados $^{[3]}$ desta forma.

Se os outros sentidos da palavra política não carregam sempre debates frutíferos com a ciência política, esta não é a mesma questão comum às duas áreas: existe ou não uma democracia técnica (JASANOFF, 2005)? É em torno desta questão chave de expertise e do papel estranho deste ser híbrido, o especialista, que é feito o ponto de junção entre as teorias da democracia e a questão da ciência (COLLINS, 2007). Podemos estender os princípios e os hábitos da democracia a estes sujeitos mais e mais carregados de expertise? Contrariamente ao famoso livro de Weber, não se trata aqui de opor o especialista ao política, mas de definir o tipo de política ${ }^{[4]}$ da qual depende a figura controversa do especialista.

Simplificando muito, esta área comum é compartilhada entre os que pensam que a política $^{[4]}$ pode absorver as questões técnicas sem sério questionamento e os que pensam, ao contrário, que é a novidade política ${ }^{[1]} \mathrm{e}^{[2]}$ da ciência e das técnicas que vai sempre reacender o coletivo, obrigando a inventar novas definições do público - que obriga, dito de outra maneira, a retroceder os assuntos para o segundo sentido ${ }^{14}$. Os primeiros pensam que devese definir a política ${ }^{[4]}$ pelos procedimentos (aqueles, neste caso, do debate racional), os segundos, que ela não pode se definir senão pelos objetos, coisas, "issues" que vêm cada vez a decompor (mas, para clarear este ponto, devo ter listado igualmente os diferentes sentidos do adjetivo "científico").

\section{Política = governamentalidade}

Se seguimos o destino dos "issues", percebemos que muitos terminam em um estado que poderíamos qualificar novamente como apolíticos se este não fosse justamente o sentido sobre o qual se exercem os melhores analistas vindos mais da ciência política, da história, da tecnologia que dos Science studies. De fato, o quinto e penúltimo sentido permitirá precisar, por contraste, os dois precedentes. É chamando, desta vez, Michel Foucault que poderemos o qualificar mais rapidamente.

Sob o termo um pouco pesado de "governamentalidade", Foucault soube detectar um fenômeno também bastante pesado: a natureza política ${ }^{[5]}$ daquilo que parecia até agora não pertencer em nada às áreas do político ${ }^{[2,3,4]}$. Nem a disposição dos muros de uma prisão, nem as preferências sexuais ${ }^{15}$, nem a compatibilidade dos pecados em uma ordem religiosa (QUATTRONE, 2004), nem um texto de lei, nem o teto de vidro sobre as carreiras das mulheres, nem a definição do orgasmo (LLOYD, 2005) ou da masturbação (LAQUEUR, 2004), nem o training dos cães de corrida (HARAWAY, 2007a) ${ }^{16}$ não parecem, aos olhos do

\footnotetext{
${ }^{14}$ É o sentido da distinção introduzida por M. Callon et al (2001), entre "democracia delegativa" e "democracia dialógica", a segunda vindo a ser necessária por causa dos limites da primeira em todas as questões controversas.

${ }^{15}$ Nota do editor: sic, "Ni la disposition des murs d’une prison, ni les préférences sexuelles, ni la comptabilité des péchés dans un ordre religieux". (Latour, 2008, p.667)

${ }^{16}$ ver também em francês Le Manifeste Cyborg et autres essais (HARAWAY,2007b), antologia organizada por Laurence Allard, Delphine Gardey e Nathalie Magnan.
} 
senso comum, fazer parte dos objetos políticos nem devem ser tratados nas arenas da democracia. E, entretanto, o imenso trabalho dos historiadores, das feministas, dos "arqueólogos" (no sentido de Foucault) não fizeram nada além de revelar, atrás da aparência profissional, acadêmica, técnica de todos estes "saberes" e destes saber-fazer, as formas de "poder" que se exercem de uma maneira tão mais eficaz quanto se transformou no hábito de se naturalizar.

Coisa interessante para meu esforço de calibração, digamos um texto de lei ou um hábito administrativo que é político ${ }^{[5]}$, é indicar exatamente o inverso disso pelo que comecei esta lista. Longe de vir romper as associações do coletivo, sacudir a hierarquia dos seres que a compuseram até aqui, violentar o cosmos, como o que é política ${ }^{[1]}$, a governamentalidade exerce sua violência pelo silencio total, pelo enraizamento in discutível, pela impressão de naturalidade, de evidencia que ela soube dar a todas estas instituições. E, certamente, a oposição destes dois termos, na prática, não é tão grande desde que, em ambos os casos, é o trabalho dos historiadores, o exame das feministas, a retomada dos arquivos pelos arqueólogos, e então o trabalho de outras disciplinas, de outros laboratórios, de outros pesquisadores, que permitem devolver à política ${ }^{[5]}$ aquilo que o hábito e a ignorância a fez perder. Podemos até dizer que tudo o que é político ${ }^{[5]}$ no sentido foucaultiano foi político ${ }^{[1]},{ }^{[2]}$ ou ${ }^{[3]}$, desde que ele não é mais apenas um objeto da governamentalidade que não encontramos no estado de vida controverso voltando, de acordo com o caso, alguns anos, algumas décadas, ou alguns séculos na história das ciências, e que não se envolveu, sob formas as vezes violentas, com questões de soberania. Se as vacinas participam hoje silenciosamente da governamentalidade mais administrativa, não se deve voltar muito longe para encontrar, nos laboratórios de Pasteur ou de Koch, os acalorados debates onde o coletivo do século XIX se voltava inteiramente fazendo dos micróbios aquilo do que sua sobrevivência dependia agora (EVANS, 1987). É certamente em torno desta tradição, basicamente foucaultiana, que a colaboração foi a mais fecunda entre nossas duas áreas (MAYET; NAVES, 2004).

Vemos que, ao curso de suas trajetórias, os assuntos que procuramos seguir não aparecem hoje tão visíveis. Agora que os sentidos ${ }^{[2]},{ }^{[3]} \mathrm{e}^{[4]}$ (Figura 1) permitem estabelecer ligações senão fáceis, ao menos possíveis com o que o senso comum reconhece facilmente como político, o mesmo não é verdade para os sentidos ${ }^{[1]} \mathrm{e}^{[5]}$ (Figura 1). Deve-se fazer um esforço nos dois casos para ver nestas questões, à primeira vista, "puramente técnicas" sua característica eminentemente política, seja, no primeiro, estender a lista dos seres que vêm transformar a definição do cosmos, ou que, no quinto, superar a impressão esmagadora da evidencia pela qual passa o exercício do poder instituído. Duas violências extremas, duas formas imensamente eficazes de poder/saber, que tem escapado há muito tempo das arenas políticas antes de tomar um lugar cada vez maior. A questão queda de saber como os estudos sobre as ciências e a ciência política podem colaborar para garantir a visibilidade contínua de todos estes "issues". 


\section{Múltiplos estados possíveis para os mesmos assuntos}

\begin{tabular}{l|c|c}
\hline \multicolumn{1}{c|}{ Sinônimo } & Definição & Referências \\
\hline Política $^{[1]}$ & Novas associações & História social das ciências \\
Política $^{[2]}$ & Coloca o problema do público & Dewey \\
Política $^{[3]}$ & Reinterpreta a soberania & Schmitt \\
Política $^{[4]}$ & Desafio de uma democracia & Habermas \\
Política $^{[5]}$ & Torna-se uma instituičão & Foucault \\
Politica $^{[6]}$ & O que não é cientificic $^{[2]}$ & Epistemologia \\
\hline
\end{tabular}

Figura 1. Lista dos diferentes sentidos da palavra política tais como podemos as utilizar concorrentemente na área dos estudos sobre as ciências. Fonte: Latour (2008), traduzido e editado por Guilherme Floriano.

Resumimos em um quadro (Figura 1) os primeiros resultados deste artigo. A ver a multiplicidade de sinônimos da mesma palavra política, compreendemos já a extrema ambiguidade - para não dizer a incoerência - dos estudos sobre as ciências, e é talvez uma das razões pelas quais a ciência política prestou pouca atenção até aqui em uma área tão confusa. E, entretanto, podemos ver que, se nos concentrarmos sobre o estado dos "assuntos" e não mais sobre um esforço de definição a priori do que constitui ou não constitui a política "propriamente dita", a colaboração se torna evidente.

Tanto que um mesmo caso, uma mesma causa, um mesmo "issue" pode passar por todos os sentidos diferentes. Seu movimento não será necessariamente linear, mas pode pular etapas, subir ou descer num quadro, fixar sem mover em um ou outro dos casos antes de se agitar freneticamente. Se cremos uma boa ideia tomar como exemplo típico de um assunto político $^{[5]}$ a forma dos diques escolhidos pelos engenheiros das Pontes e Estradas, não ficaremos surpresos de ver, depois da passagem do ciclone Katrina, que a questão de escolas técnicas para os diques que devem proteger Nova Orleans se tornou, repentinamente, político ${ }^{[2]}$ e até por causa da gestão catastrófica do presidente Bush, político $^{[3]}$ : como não pode assegurar a proteção de seus concidadãos, de repente há a questão obscura dos diques atrelada à grande questão da soberania. Um deslocamento no espaço terá os mesmos efeitos que um deslocamento no tempo: encontraremos através do mundo, em todos os estados políticos possíveis, as "causas" aparentemente similares de abastecimento de água, de transporte público, de esgoto, de proteção das espécies ou de energia renovável: instituições para além dos Alpes, controvérsias aquém. Para tratar em comum estes objetos, não nos falta, ao que me parece, senão um pequeno esforço de coordenação. Contanto que se perceba que nenhum dos significados que revelei até aqui traz alguma distinção particular com outra atividade, outra esfera, outra área que será particular às "ciências". Todos 
designam o mesmo pote comum e qualificam somente as etapas, se ouso dizer, no cozimento dos ingredientes que compõem este melting pot.

Não será o mesmo com o sexto sentido da palavra política. Mas para defini-lo, devemos prolongar nosso esforço de esclarecimento e passar agora aquele da palavra "ciência".

\section{Quatro sentidos distintos da palavra "científico"}

Pode parecer insensível precisar, em algumas páginas, o uso de um termo tão polissêmico. Entretanto, é impossível calibrar a colaboração entre os estudos sobre as ciências e a ciência política sem se esforçar em definir as diferentes acepções já que esta é justamente a particularidade de nossa área ao invés de fazer um uso tão problemático quanto possível.

Se há um termo que as ciências sociais não deveriam mais empregar sem inquietação, como se os Science studies não tivessem passado por aqui, é a palavra "ciência" (eu deixo de lado a palavra "social", que deveria aborrecê-los ainda mais, mas isso é outro assunto ${ }^{17}$...). O ponto importante e, reconheço, um pouco polêmico, é que, para começar esta sessão, devemos de partida admitir que a ciência não é o que esclarece, mas o que convém de início ser esclarecido. Ela deve escapar do papel de recurso indiscutível àquele de objeto de uma investigação sistemática (from resource to topic). Em outras palavras, para que a discussão ocorra, devemos aceitar que nós não saibamos de maneira alguma o que quer dizer o termo "científico" - que é apenas a contrapartida, veremos, do que pedi ao início da sessão precedente para a palavra "política”. Assim como não existe uma área predefinida do político, não existe um método, uma área, uma disciplina, uma esfera que será "científica" ${ }^{18}$.

\section{Científico = razoável e objetivo}

Passo bem rápido sobre um primeiro sentido da palavra científico ${ }^{[1]}$ (utilizarei aqui ainda os índices), pela qual designamos um sinônimo, mais vago, de "razoável", "rigoroso", "honesto", "sério", mistura muito mal definida de qualidades morais e de hábitos de boa companhia. Não que este termo não seja importante, antes pelo contrário. Mais e mais estudos quase etnográficos e até etnológicos sobre o comportamento do "cientista" em seu próprio corpo - até mesmo em seus hábitos alimentares! - nos mostra à qual ponto é este pacote de qualidades que designamos costumeiramente por este termo, sem querer confessar: uma maneira de ser, de se vestir, de se comportar, de tomar suas distancias, de ser atento, e se podemos resumir em uma expressão, de manifestar de uma maneira ou de outra o pathos e a objetividade (DASTON, 1992; SHAPIN, 1994; SHAPIN; LAWRENCE, 1998). Pathos que poderemos também encontrar mais sob as ações de três conselheiros de Estado, que sob os jalecos brancos dos laboratórios (LATOUR, 2002). Mas esta acepção muito

\footnotetext{
${ }^{17}$ A esse respeito ver Latour (2006).

${ }^{18}$ Ao contrário do livro de Favre, (2005) que toma como ponto de partida que, para descobrir o "fundamento" epistemológico da ciência política, deve-se, inicialmente, definir uma "visão científica do mundo”.
} 
especial, se interessa enormemente à antropologia, não ressoa muito com as questões de ciência política e destaca-se mais a história das personagens. Lembremos apenas que, neste sentido banalizado, dizer que um enunciado é "científico" não significa nada além que "digno de fé", sem explicitar em nada a natureza da cadeira de pessoas razoáveis que atestam isso. Assim como o adjetivo "objetivo" designa às vezes uma qualidade dos assuntos e as vezes uma qualidade dos "objetos", o adjetivo "científico" muda completamente o sentido pelo qual nos servimos para designar um estado de espírito ou a relação com um tipo particular de objeto.

\section{Científico $=$ que é distinto da política}

É o que vemos bem ao falar do segundo sentido. Este nos interessa de forma decisiva já que é por ele que se inventa a distinção própria entre as duas áreas da ciência e da política. Não será errado definir os Science studies como a área que, longe de tomar a distinção como adquirida, esforçou-se, ao contrário, para descrever a época onde ela é inventada. De forma, devemos reconhecer, bastante desconfortável ao invés de se instalar de um ou de outro lado do muro, colocou seus aparelhos sobre o muro - e enquanto ele era construído.

Como eu disse no começo, o caso mais brilhante, aquele que teve maior impacto até mesmo na França (até na ciência política), é certamente aquele da relação entre Boyle e Hobbes relato no livro mestre de Steve Shapin e Simon Schaffer (1993). Mas podemos ir ainda mais longe e retornar não à distinção entre "ciência" e "política", agora muito claramente ligada às formas históricas nas quais a história sobre três séculos começa a se clarear, mas, agora, sobre a origem mesmo da diferença capital entre convicção e persuasão. De fato, a Revolução científica é herdeira de uma diferença muito mais antiga que uma outra obra-prima mais recente, aquela de Reviel Netz (2003), nos permite ainda historicizar.

De onde vem, de fato, a ideia assombrosa - aquela que entusiasma ainda agora os leitores de Górgias de Platão - que existiria, além da retórica, um outro caminho, aquele da prova indiscutível (DETIENNE, 2003)? Para retomar os termos iluminados por Barbara Cassin (1995), de onde provém a diferença tão decisiva entre os termos, de início sinônimos, de apodeixis que vai dar o raciocínio apodítico, e de epideixis que dará a eloquência e suas aparências enganosas? Se queremos remontar à fonte que vai dar, bem mais tarde, a separação entre as áreas da Ciência e da Política, é até então que devemos ir. Qual leitor não está convencido que existe bem "ainda" uma diferença essencial, indiscutível, indispensável, tão intelectual quanto moral, entre a discussão racional e científica de um lado, e, de outro, o debate indefinido que deve chamar, para ser fechado, os recursos retóricos?

Ora, é justamente o imenso mérito do livro de Netz que nos leva, por um trabalho tão rigoroso quanto aquele de Shapin e Shaffer, mais próximo do "laboratório" de onde vai surtir esta distinção. Para resumir em uma frase: apodítica é a transposição, na linguagem da filosofia, de uma prática dos geômetras gregos que não obtiveram sucesso em transferir as necessidades de um ponto à outro da prova de que porque se absteve, com um cuidado obsessivo e ciumento, de deixar os estreitos limites de um trabalho formal sobre os diagramas geométricos. A ideia de uma diferença radical entre apo- e epi-tíditica vem de um desvio, 
pelos platônicos, de uma prática esotérica da qual eles nunca conseguiram imitar a técnica (a geometria "caminhava" pois os diagramas não tinham algum conteúdo), mas eles somente transpuseram o efeito retórico, de fato surpreendente: a possibilidade de transferir passo a passo um tipo de certeza indiscutível. Sem entrar em detalhes, nos encontramos transportados ao cerne da epistemologia (política) ${ }^{19}$ : os platônicos vão reinventar a vida da cidade importando uma novidade radical que não tem outro conteúdo senão a reiteração sem fim de que existe uma diferença radical entre filosofia e sofismo, entre apo- e epitidico... É assim que a razão vai triunfar aparentemente sobre o sofisma.

Observaremos, então, que se dissermos que um discurso, que um fato, que uma disciplina ou que alguém é cientista ${ }^{[2]}$ neste sentido, não definimos jamais um conteúdo particular, desenhamos simplesmente a diferença entre o interior e o exterior, traçamos um território, rejeitamos qualquer coisa que, mais tarde, vai se tornar a área própria da política definida justamente como o que não écientífico. É então que a epistemologia política se torna sequer epistemologia ${ }^{20}$.

É esta operação de afastamento que vai nos obrigar a definir um sexto sentido da palavra política ${ }^{[6]}$, sem outro conteúdo do que não ter as qualidades racionais que imaginamos ser aquelas das ciências. Doravante, faremos como se toda ideia da política dependesse desta definição da ciência, e vice versa, os dois sentidos formando um casal infernal que não pode nem se entender, nem se divorciar, mas que toma como única identidade o fato de estarem radicalmente separados (inseparáveis) um do outro... "Ah, é científico $^{[2]}$ ? Então não é político ${ }^{[6] " ! ~ T e r m o ~ s u r p r e e n d e n t e ~ q u e ~ n a ̃ o ~ t e m ~ o u t r o ~ o b j e t o ~ s e n a ̃ o ~}$ o de submeter a uma exclusão de outra atividade sem qualquer outro conteúdo do que esta exclusão em si. Mas o termo tem uma eficácia surpreendente uma vez que, sem exagero, podemos traçar uma linha contínua do Górgias até os dias de hoje: a arma da epistemologia é pouco contundente como se vinte e cinco séculos tivessem, pelo contrário, conseguido apenas aguçá-la constantemente!

É, evidentemente, estes dois sentidos, o de científico ${ }^{[2]}$ e de político ${ }^{[6]}$ que utilizávamos antigamente, nos tempos de Louis Althusser, por exemplo, para distinguir "enfim" a "ciência" da "ideologia". Coisa mais surpreendente, é ainda estes vocábulos que pretendemos continuar a usar afim de patrulhar a fronteira entre as "questões puramente técnicas" e a tendência a "politizar ${ }^{[6]}$ indevidamente o que não deve jamais sê-lo", mesmo que as questões de hoje escapem totalmente e à esta ideia da ciência ${ }^{[2]}$ e à esta noção da política ${ }^{[6]}$. Não admira que tenhamos problemas em nos virar!

Para ser mais direto, o senso comum reconhece geralmente a política ${ }^{[6]}$ apenas como o que cai do eixo da epistemologia, como o negativo cujo científico ${ }^{[2]}$ seria o positivo. Compreendemos sem problemas que se, infelizmente, a ciência política toma este sentido de

\footnotetext{
${ }^{19}$ Cf. Latour (2008)

${ }^{20}$ Deve-se sempre ter cuidado para distinguir "epistemologia política" que engloba os estudos sobre a origem e a gestão das diferenças entre ciência e política da "epistemologia (política)" que, sob pretexto de definir a ciência, coloca entre parênteses que é tudo sobre política e nada mais (LATOUR, 2001b).
} 
ciência em seu título, ela terá algumas dificuldades para digeri-lo. É que ela teria tomado, para designar seu método de pesquisa, o termo polêmico por excelência que teria tornado seu objeto de estudo - a política ${ }^{[6]}$ - um mero resíduo!

Mas o ponto mais fundamental ao qual já fiz alusão e sobre o qual retornarei na conclusão é que, de todos os sentidos que percorremos até aqui, é o primeiro - e veremos que é o único - que se dedica exclusivamente a distinguir da política. Os cinco sinônimos que listamos na sessão precedente, nenhum procura separar uma área própria, aquele do político. Todos qualificam etapas distintas na trajetória das mesmas questões, um pouco como os astrônomos tomaram o hábito de nomear por termos distintos (anão vermelho, supergigante, supernova, pulsar, buraco negro, etc.) os estados distintos das mesmas estrelas. O objetivo de todos estes termos não é traçar um limite entre o que pertenceria à objetividade científica e o que depende, infelizmente, das dificuldades políticas, mas definir como o coletivo gerencia melhor ou pior a descrição destes casos.

\section{Científico = levado à prova diante dos porta-vozes}

É exatamente a este limite que o terceiro sentido da palavra "ciência" escapa, assim que este termo se tornar objeto de uma investigação minuciosa ao invés de ser "In hoc signo vinces" de quem se sonha na véspera das batalhas. Podemos afirmar que os Science studies foram constituídos quando quisemos definir a atividade científica ${ }^{[3]}$ sem justamente invocar a questão epistemológica por excelência (PESTRE, 2006), quer dizer, sem aceitar que suas pesquisas sejam mobilizadas na grande guerra da ciência ${ }^{[2]}$ contra a política ${ }^{[6]}$. Os mal entendidos que nossa área suscitou de início, vem de outro lugar: certos pesquisadores das ciências naturais e sociais creram que tomávamos a iniciativa de politizar ${ }^{[6]}$ as ciências ${ }^{[2]}$ enquanto era uma questão de as estudar positivamente ignorando enfim a questão da demarcação. Daí, as batalhas entre o "realismo" e o "relativismo" cheias de significado para aqueles que seguravam à distância de um braço Lebaraum, mas quase tão irrisórias, para nós, quanto aqueles entre Petitsboutistes e Grosboutistes. Acreditávamos que partíamos à guerra contra a Razão, enquanto desertávamos, pelo contrário, seu combate, que fundíamos nossas espadas para com elas forjar arados!

Entregue ao segundo sentido (e, consequentemente, a sua pesada contraparte política $^{[6]}$ o adjetivo científico ${ }^{[3]}$ não se refere aos mesmos fenômenos. Ele nos direciona primeiro em direção a novos lugares, como o laboratório, que ele capta como prático e cuja estranheza antropológica aparece agora em plena luz (HOUDART, 2008; KNORRCETINA, 1999). Prática pela qual nos surpreendemos pelo fato de ser pouco descrita diante de nós como os objetos que ela revela diferem inteiramente da ideia de que a ciência geralmente é feita. Não é o objetivo deste artigo resumir o conteúdo, mas desejo assinalar um dos pontos que poderiam servir para captar as preocupações da ciência política.

É científico ${ }^{[3]}$, neste sentido, todo dispositivo que permite fazer falar os fenômenos cujo pesquisador se torna, de alguma forma, o porta-voz. Quando sabemos a imensa literatura e as dificuldades extremas para definir, em ciência política, estas noções de representantes, 
de intermediários, de intérpretes, podemos imaginar a possível colaboração com a literatura cada vez mais rica que descreve como os pesquisadores representam seus objetos (LYNCH, 1985; RHEINBERGER, 1997; ATTEN; PESTRE; HERTZ, 2002). Que um dos sentidos da palavra representação se aplica mais aos humanos em seu sentido tradicionalmente político (do lado de Hobbes), enquanto o outro sentido da palavra representação se aplica mais às coisas eu seu sentido tradicionalmente científico (do lado de Boyle) não impede que toda controvérsia já, na prática, misturou as duas formas (STENGERS, 1993).

"Em nome de quem você fala?" "Você é testemunha confiável?" "É você quem fala ou aqueles em cujo nome você fala", etc. sentimos que todas estas questões são comuns, seja do aquecimento global, do cálculo das estatísticas de desemprego, ou da representatividade dos sindicatos. Para evitar ver o que há de comum à ciência ${ }^{[3]}$ como à política, argumentamos às vezes que, no primeiro caso, são "os fatos que falam por eles mesmos”, quanto no segundo, são somente os humanos que falam "no lugar" de outros humanos. Mas, primeiro, não é mais fácil fazer falar os humanos que os objetos e, além disso, os fatos jamais falam por si mesmos sem um dispositivo, infinitamente complexo, para fazê-los falar (DASTON; GALISON, 2007). A questão comum é mais saber quais são os testes que são feitos e como nos asseguramos, de acordo com o caso, da recalcitrância dos objetos sobre os quais falamos. Seja demonstrações de ratos ou "demonstrações" de rua, devemos sempre demonstrar. E se o demonstramos, seremos sempre contraditos, deveremos sempre encontrar um instrumento idôneo, delimitar a arena ajustada à este tipo de discussão, convocar o grupo de testemunhas capazes de julgar, precisar os testes que farão a diferença, imaginar os procedimentos pelos quais poderemos fechá-lo.

Além disso, há alguma ironia em escrever um artigo para convencer colegas universitários a calibrar nossas definições, enquanto, de toda parte, se multiplicam dispositivos que estão trinta anos à frente de nosso vocabulário e que já, de mil formas, regularam na prática a questão cujo único enunciado escandaliza com demasiada frequência! Quando o IPCC se reuniu em Paris em fevereiro de 2007 para servir de assembleia ad hoc à questão do aquecimento global e decidir sua causalidade precisa, à que serviria opor, ainda, os recursos da ciência política e dos Science studies? Sentimos que esforços para trazer tal assembleia para o leito de Procusto da oposição entre a verdadeira ciência ${ }^{[2]}$ e a falsa política $^{[6]}$ - mesmo que não fracassem - não possui qualquer sentido e já nos dirigimos a uma questão diferente, muito à nossa frente: qual epideixis pode servir de sustentação à apodeixis?

Notemos que nenhuma característica desta antropologia da ciência difere radicalmente dos cinco primeiros sentidos da palavra política que vimos. Certamente, há diferenças: não conduzimos uma experiencia de laboratório como dirigimos uma greve, um conselho de administração ou um comitê de especialistas. Mas com certeza não encontramos A diferença imposta pelo sentido precedente. As competências, as carreiras, os problemas, as paixões, tudo é diferente: o pote é comum, assim como as questões, os “issues" que fervem. É este o objeto comum, a coisa comum (LATOUR; WEIBEL,2005). Enquanto fosse 
impossível, com o sentido precedente, conduzir uma investigação seguindo os problemas onde quer que nos levem, por causa dos peso do termo ciência ${ }^{[2]}$ (e de seu incômodo vis-avis, a política ${ }^{[6]}$ ), nada nos impede de passar agora, sem solução de continuidade, do laboratório mais esotérico à mais quente e barulhenta assembleia. Não é a antiga fronteira entre ciência e política que devemos seguir, mas as etapas sucessivas das mesmas questões.

\section{Científico = logística de dados}

Se hesitamos em ver em qual ponto a atividade científica ${ }^{[3]}$ não precisa ser compreendida para se distinguir a priori das situações políticas, talvez seja também porque a confundimos com um quarto sentido, tão diferente quanto este é do segundo. Se você assegura com confiança que um enunciado é "científico [4]", é mais porque você aponta para a amplitude do trabalho de coleta de dados na qual ele é apenas a ponta. Ao contrário do primeiro sentido, o que te tranquiliza não é, de forma alguma, o fato de que aquele que o afirma é "científico[1]", que parece "sério", "razoável”, "distante" ou "obsoleto", estas não são qualidades subjetivas, sua etologia à qual você faz alusão. Não, o que lhes permite avançar é que vocês puderam medir, muitas vezes indiretamente, que existe, para apoiar seus dizeres, um fluxo contínuo de formas calibradas e arquivadas, o que chamamos de dados, os "data", o que propus chamar, em vez disso, dados seus custos e a dificuldade de os obter, de "obtidos" (os sublata)... Científico ${ }^{[4]}$ significa que agora estamos apoiados sobre uma infinidade de outras evidências em direção às quais podemos voltar, em caso de contestação, por um caminho sem ruptura.

A internet tem acesso tão difundido às bases de dados que todos, hoje, podem verificar por si próprios o que quer dizer garantir uma declaração "sobre os dados". Mas não se deve esquecer que se trata de um fenômeno que remonta a vários séculos. A digitalização das bases de dados promove, em parte, a fluidez e o acesso (apesar da tendência inversa à apropriação e ao segredo ${ }^{21}$ ), mas apenas prolonga o que já se fazia pelas coleções, arquivos, campanhas de prospecção, pesquisas estatísticas. Qualquer disciplina aprendida, seja geologia, obstetria, etnografia, pedagogia, management, tribologia, ciência política, etc., vai se definir pela importância, pelo custo, pela qualidade, pela manutenção de sua rede de bases de dados. Ela será mais ou menos científica ${ }^{[4]}$ de acordo com a amplitude dessa rede.

O que não significa dizer, de maneira alguma, que ela será científica ${ }^{[3]}$ até agora! Ninguém teria a ideia de julgar um fundo de pensão pela amplitude de seu capital, julgamolo em princípio pelo rendimento que ele pôde lhe dar; da mesma forma, não haveria nenhum sentido em julgar que uma disciplina é científica ${ }^{[3]}$ sob o pretexto de que ela tem "muitos dados": ela deve, primeiro, nos mostrar o que é capaz de fazer com seu capital, como ela soube torna-lo frutífero em objetos recalcitrantes. Mais uma vez, não se deve confundir os sentidos inteiramente distintos deste perigoso adjetivo "científico". Existem tantas áreas científicas $^{[4]}$ com dados cegos que não produzem um único resultado científico ${ }^{[3]}$ digno de

\footnotetext{
${ }^{21}$ cf. Galison (2005b, p. 590-599).
} 
confiança, mesmo que tenham conseguido inchar em importância aqueles que emprestam da ciência ${ }^{[1]}$ todo o pathos de objetividade. Se há uma coisa da qual os Science studies nos libertou, é da crença que é fácil imitar o estilo científico e que basta ser chato para dizer coisas cientificamente exatas... Uma coisa é certa: não podemos utilizar a palavra científico sem especificar o índice.

Esperamos que a adição de alguns índices para desvendar os sinônimos da palavra "ciência" ajudará as ciências sociais a não se deixar intimidar: elas não terão, de forma alguma, o mesmo aspecto de acordo com o fato de serem ciências ${ }^{[3]}$ sociais ou ciências ${ }^{[2]}$ sociais... e, sobretudo, seu impacto político será sem comparação. Émile Benaviste ficou espantado que o génio da língua francesa não extraísse da palavra latina "scientia", ao invés do único "scientifique", termos como "sciental" ou "scientaire"22. Isso teria-nos permitido, de fato, não misturar os termos cuja distinção parece essencial à nossa vida comum.

\section{Conclusão: cosmopolítica}

Recapitulando na figura 2 as diferentes acepções apresentadas neste artigo, vemos mais claramente ainda que apenas um sentido (em acinzentado) se define apenas pelo contraste com outro. É o único que podemos dizer traçar, de fato, esferas incomensuráveis. Todos os outros designam, mais ou menos precisamente, estados diferentes (e às vezes sucessivos) nos quais podem se encontrar as questões fabricadas pelo coletivo.

\begin{tabular}{|c|c|c|c|}
\hline Sinônimos de & Politico & Sinônimos de & Científico \\
\hline Político $^{[1]}$ & Nova associação & & \\
\hline Político $^{[2]}$ & O público e seus & & \\
\hline & problemas & & \\
\hline Político ${ }^{[3]}$ & A soberania & & \\
\hline Político $^{[4]}$ & Discussão racional & & \\
\hline Político $^{[5]}$ & Instituição invisível & Científico $^{[1]}$ & Razoável \\
\hline \multirow[t]{3}{*}{ Político ${ }^{[6]}$} & Não científico & Científico $^{[2]}$ & Não político \\
\hline & & Científico $^{[3]}$ & Produto de testemunhas \\
\hline & & Científico $^{[4]}$ & Mobiliza dados \\
\hline
\end{tabular}

Figura 2. Recapitulação dos diferentes sentidos das palavras "político" e "científico". Fonte: Latour (2008), traduzido e editado por Guilherme Floriano.

Aqui, então, muito grosseiramente esboçado, como se apresenta do lado dos Science studies (tal qual, ao menos, interpreto) a questão delicada da relação entre as palavras "ciência" e "política". As nuances que introduzi correm o risco de parecer, aos olhos da ciência política, às vezes minuciosas e rudimentares demais. Daí a importância de proceder lentamente.

\footnotetext{
${ }^{22}$ Nota do tradutor: para efeitos de melhor compreensão do argumento do autor, decidimos manter estas três palavras no francês, como originalmente escritas.
} 
Quanto utilizamos muito rapidamente os dois termos, emprestamos sem pensar a única definição da palavra científico ${ }^{[2]}$ que não tem outro conteúdo senão definir, por padrão, a política ${ }^{[6]}$. Imediatamente desaparecem todos os outros sentidos que não têm por objeto definir as áreas distintos, esferas de atividade autônomas. De uma só vez, a colaboração entre as disciplinas como a ciência política e a política das ciências se torna totalmente impossível, ou consiste em tomar como ponto de partido as duas caricaturas para, em seguida, e tentar uni-las: haveria "também" nas ciências os "aspectos" e as "dimensões políticas"... Apesar da amplitude dos comentários no livro de Weber, devemos insistir, ao contrário, para dizer que não há jamais alguma relação a estabelecer-se "entre o cientista e o político", a ciência e a política, pela boa e simples razão de que essas área a serem colocados em relação não existem e jamais existiram separadamente.

Tentei neste artigo propor uma calibração de termos para definir um fenômeno tal que observamos desde minha capela, aquela dos Science studies. Estou convencido que é comum àquele da ciência política, mesmo se o uso diferente que fazemos dos temos "ciência" e "política" não facilite a superposição dos casos. Dito de outra forma, me parece que o verdadeiro fenômeno a ser traçado não se situa em nenhuma das duas disciplinas, mas na evolução mais ou menos rápida das questões cujas etapas sucessivas devem ser qualificadas muito precisamente. "Ciência" e "política" não qualificam áreas de atividade ou de competência, mas estados - como falamos de estado líquido ou gasoso - nos quais se encontram objetos controversos que tem vocação para compor o mundo comum. É à definição precisa destes estados que poderiam, me parece, colaborar o que poderíamos chamar de política das ciências e as diversas ciências do político.

Os Science studies beneficiariam certamente de tal colaboração, tanto o uso que fizemos da palavra "política" - sem falar da palavra "social" - introduziu a confusão. Talvez a ciência política poderia, também, se beneficiar de uma maneira de falar assim das ciências ${ }^{[3]}$ para reencontrar as ligações com o mundo, com o cosmos, desde que é, no fundo, disso que ela trata. Daí o termo geral de cosmopolítica ${ }^{23}$ que devemos escolher para cobrir a união dos termos da figura 2 - todos menos um. A amplitude das crises ecológicas torna cada vez mais fácil compreender que toda política sempre foi uma cosmopolítica, quer dizer, uma política do cosmos e que, neste sentido, sempre tivemos que lidar com o que chamei uma política orientada-ao-objeto (LATOUR, 2005). Trabalho considerável, reconheço de bom grado, mas que não seria pelo menos inviável.

Ao passo que, durante tantos séculos, esperamos voar em auxílio da infeliz política pelo raciocínio apodítico oferecido por uma ou outra ciência ${ }^{[3]}$ (teologia, física, biologia, economia, genética, teoria de sistemas, candidatas não faltaram...) vemos hoje que, pelo contrário, é a política, mas uma política bem diferente daquela que tanto desprezamos, que deve vir em socorro, servir de asilo e abrigo às ciências positivas ${ }^{[3]}$. Não se trata, no fundo, de nada menos que desinventar a solução platônica que, querendo fundar a política na razão,

\footnotetext{
${ }^{23}$ No sentido de Stengers (1996), mas também de Beck (2006).
} 
acabou por perder a ciência e a política. Que inversão! Será tão absurdo pensar que as ciências políticas e os estudos sobre as ciências poderiam contribuir, unindo suas forças, para elaborar uma alternativa ${ }^{24}$ ?

\section{Referências}

ATTEN, M.; PESTRE, D.; HERTZ, H. (200). L'administration de la preuve. Paris: PUF.

BARTHE, Y. (2006) Le pouvoir d'indécision: la mise en politique des déchets nucléaires. Paris: Económica.

BECK, U. (2006). Qu'est-ce que le cosmopolitisme?, Paris: Aubier, 2006.

CALLON, M.; LASCOUMES, P.; BARTHE, Y. (2001). Agir dans un monde incertain. Essai sur la démocratie technique, Paris: Seuil.

CALLON, M; RABEHARISOA, V. (1999) Le pouvoir des malades. Paris: Presses de l'École nationale des mines de Paris.

CARDON, D. et al. (1998). "Mais qui fait bouger le compteur du Téléthon? Une construction télévisuelle de la solidarité”. In: Sciences sociales et santé, vol.16, n.3, p. 17-40

CASSIN, B. (1995). L'effet sophistique. Paris: Gallimard.

CHATEAURAYNAUD, F; TORNY, D. (1999). Les sombres précurseurs. Une sociologie pragmatique de l'alerte et du risque. Paris: EHESS.

COLLINS, H; EVANS, R. (2007). Rethinking expertise. Chicago: The University of Chicago Press.

DASTON, L.; GALISON, P. (2007). Objectivity. Chicago: The University of Chicago Press.

DASTON, L. (1992). "Objectivity and the Escape from Perspective”. In: Social Studies of Science, vol.22, n.4, p. 597-618.

DE VRIES, G. (2007). "What is political in subpolitics? How Aristotle might help STS". In: Social Studies of Science, vol.37, n.5, p. 781-809.

DESROSIÈRES, A. (1993). La politique des grands nombres. Histoire de la raison statistique. Paris: La Découverte.

DETIENNE, M. (dir.). (2003). Qui veut prendre la parole?, Paris: Seuil.

DEWEY, J. (2003). Le public et ses problems. Pau: Publications de l'Université de Pau/Léo Scheer.

DONEGANI, J-M; SADOUN, M. (2007). Qu'est-ce que la politique? Paris: Gallimard.

FAVRE, P. (2005). Comprendre le monde pour le changer: épistémologie du politique. Paris: Presses de Sciences Po.

EVANS, R. J. (1987). Death in Hamburg. Society and politics in the cholera years 1830-1910. Harmondsworth: Penguin Books.

FEUER, L-S. (2005). Einstein et le conflit des générations. Bruxelles: Complexe.

FOURNIAUX, J-M. (2007). "L’institutionnalisation du débat public”, In: Projet, vol.297, p.13-21.

\footnotetext{
${ }^{24}$ Agradeço profundamente Dominique Linhardt e Dominique Pestre por suas observações.
} 
GALISON, P. (2005a). L'empire du temps: les horloges d'Einstein et les cartes de Poincaré. Paris: Robert Laffont.

GALISON, P. (2005b). "Removing Knowledge". In: LATOUR, B.; WEIBEL, P. (Eds), Making Things Public. atmospheres of democracy. Cambridge: MIT Press, p.590-599.

GILBERT, C. (dir.). (2003). Risques collectifs et situations de crise: apports de la recherche en sciences humaines et sociales. Paris: L'Harmattan

GRAWITZ, M; LECA, J. (1985). Traité de science politique - I: La science politique, science sociale, l'ordre politique. Paris: PUF.

HACKETT, E. et al. (Eds). (2007). The Handbook of Science and Technology Studies. $3^{\circ}$ ed. Cambridge: MIT Press.

HARA WAY, D. (2007a). When Species Meet. Minneapolis: Minnesota University Press.

HARAWAY, D. (2007b). Le Manifeste Cyborg et autres essais. Sciences, fictions, feminisms. Paris: Exils Éditeur.

HECHT, G. (2004a). Le rayonnement de la France: energie nucléaire et identité nationale après la Seconde Guerre Mondiale. Paris: La Découverte.

HOUDART, S. (2008). La cour des miracles: ethnologie d'un laboratoire japonais. Paris: CNRS.

JASANOFF, S. (2005). Designs on Nature: science and democracy in Europe and the United States. Princeton, Princeton University Press.

JOLY, P-B; MARRIS, C.; HERMITTE, M-A. (2003). “À la recherche d'une "démocratie technique'. Enseignements de la conférence citoyenne sur les OGM en France”. In: Natures sciences sociétés, vol.11, n.1, p.3-15

JOLY, P-B; MARRIS, C. (2003). "La participation contre la mobilisation ? Une analyse comparée du débat sur les OGM en France et au Royaume-Uni”. In: Revue internationale de politique comparée, vol.10, n.2, p.195-206.

KNORR-CETINA, K. (1999). Epistemic Cultures. How the Sciences Make Knowledge, Cambridge, Harvard University Press.

LAGROYE, J. (2003). La politization. Paris: Belin.

LAQUEUR, T. (2004). Solitary sex: a cultural history of masturbation. New York: Zone Books.

LATOUR, B. (1988). “A Relativist Account of Einstein's Relativity “, In: Social Studies of Science, vol.18, 1988, p. 3-44.

(1999). Politiques de la nature. Comment faire entrer les sciences en démocratie. Paris: La Découverte.

(2001a). Pasteur: guerre et paix des microbes, suivi de Irréductions, Paris, La

Découverte.

(2001b). L'espoir de Pandore. Pour une version réaliste de l'activité scientifique, Paris, La Découverte.

(2002). La fabrique du droit. Une ethnographie du Conseil d'État. Paris: La Découverte. 
LATOUR, B. (2005). "From Realpolitik to Dingpolitik. How to Make Things Public. An Introduction “. In: LATOUR, B.; WEIBEL, P. (Eds). Making Things Public. atmospheres of democracy. Cambridge: MIT Press, p. 1-31. (2006). Changer de société. Refaire de la sociologie, Paris, La Découverte. (2008). "The Netz-Works of Greek Deductions. A Review of Reviel Netz: The Shaping of Deduction in Greek Mathematics”. In: Social Studies of Science, vol.38, n.3, p. 441-459.

LATOUR, B.; WEIBEL, P. (Eds). (2005). Making Things Public. atmospheres of democracy. Cambridge: MIT Press.

LIPPMANN, W. (2008). Le public fantôme. Paris, Démopolis.

LLOYD, E. (2005). The Case of the female orgasm: bias in the science of evolution, Cambridge, Harvard University Press.

LOLIVE, J. Contestations du TGV Méditerranée. Paris: L'Harmattan, 1999.

LYNCH, M. (1985). Art and Artifact in Laboratory Science: a study of shop work and shop talk in a research laboratory. Londres: Routledge.

MACKENZIE, D. (2006). An Engine not a camera. how financial models shape market, Cambridge, MIT Press.

MARRES, N. (2007). “The Issues deserve more credit: pragmatist contributions to the study of public involvement in controversy”. In: Social Studies of Science, vol.37, n.5, p.759780.

MARRES, N. (2005). "No Issue, No Public. Democratic Deficits after the Displacement of Politics"., PhD in Philosophy. Amsterdam: University of Amsterdam.

MEYET, S.; NAVES, M-C; RIBÉMONT, T. (2004). Travailler avec Foucault: Retours sur le politique. Paris: L'Harmattan.

NETZ, R. (2003). The Shaping of deduction in Greek mathematics: a study in cognitive history. Cambridge, Cambridge University Press.

OFFENSTADT, N. et al. (dir.). (2007). Affaires, scandales et grandes causes: de Socrate à Pinochet. Paris: Stock.

PESTRE, D. (2006). Introduction aux Science Studies. Paris: La Découverte, 2006.

PESTRE, D; NÉEL, L. (1990). Le magnétisme et Grenoble. Paris: Éditions du CNRS.

QUATTRONE, P. (2004). "Accounting for God. accounting and accountability practices in the Society of Jesus (Italy, 16th-17th centuries)". In: Accounting, Organizations and Society, vol.29, n.7, p. 647-683.

REYNIÉ, D. (1998). Le Triomphe de l'opinion publique. L'espace public du $16 \mathrm{e}$ au 20e siècle, Paris, Odile Jacob.

RHEINBERGER, H-J. (1997). Toward a history of epistemic thing: synthetizing proteins in the test tube. Stanford: Stanford University Press.

SHAPIN, S; SCHAFFER, S. (1993) Le Léviathan et la pompe à air: Hobbes et Boyle entre science et politique. Paris: La Découverte. 
SHAPIN, S. (1994). A Social history of truth: gentility, civility and science in 17th century England. Chicago: Chicago University Press.

SHAPIN, S.; LAWRENCE, C. (Eds). (1998). Science Incarnate. historical embodiments of natural knowledge. Chicago, University of Chicago Press.

STENGERS, I. (1993). L'invention des sciences modernes. Paris: La Découverte.

STENGERS, I. (1996). Cosmopolitiques: La guerre des sciences. Paris: La Découverte.

TRESCH, J. (2005). “Cosmogram”, In: M. Ohanian, M; J.-C. Royoux (Eds). Cosmograms. New York: Lukas \& Sternberg, p. 67-76.

ZASK, J. (2000). L'opinion publique et son double (vol. II): John Dewey, philosophe du public. Paris, L'Harmattan.

\section{Sobre o autor}

\section{Sobre o tradutor}

\begin{abstract}
Bruno Latour
É professor e diretor científico na Sciences Po. A lista de suas publicações e a maior parte de seus artigos estão disponíveis em www.bruno-latour.fr. Seu trabalho é centrado na prática científica e, em parte, sobre as ligações entre teoria política e filosofia da ciência
\end{abstract}

\section{Guilherme de Matos Floriano}

É doutorando pelo Programa de Pós Graduação em Ciências Sociais na Faculdade de Ciências e Letras de Araraquara da UNESP (FCLAr), com bolsa CAPES. 